\title{
GREGUERÍA Y NOVELA EN RAMÓN GÓMEZ DE LA SERNA
}

Antonio del Rey Briones

Casi todos los críticos que se han ocupado de la novela de Gómez de la Serna -no muchos, por cierto- coinciden en señalar la influencia determinante de la greguería en su génesis y desarrollo, lo cual supone limitar considerablemente su significación propia ${ }^{1}$.

No pretendemos cuestionar la importancia de la greguería en la obra ramoniana -algo, por lo demás, fuera de toda discusión-, ni negar que, en mayor o menor medida, de una u otra forma, se halla presente en toda la producción del escritor -no sólo la novela-posterior a 1910. Pero de ahí no debe colegirse necesariamente que la novela de Ramón sea un mero apéndice de la greguería, como se ha dicho. Es preciso, pues, rectificar esta interpretación abusiva y situar en sus justos términos la relación entre ambas especies literarias.

El error procede, a nuestro juicio, de considerar la greguería como fundamento y clave última del arte literario de Ramón, cuando en realidad no es sino una consecuencia de los principios que informan la estética general del escritor; de igual manera que los restantes géneros cultivados por Ramón son asimismo una consecuencia de idénticos principios. Así pues, la vinculación entre greguería y novela en Ramón debe plantearse desde unos nuevos presupuestos: no hay subordinación o dependencia de la segunda respecto a la primera, sino comunidad de principios artísticos entre ambas,

1 Tal es el parecer de Santiago Vilas, para el que "La novelística de Ramón es una gregueria continuada, una greguerización de los temas y de la novela en general" (Santiago Vilas, "Ramón Gómez de la Serna», en El humory la novela española contemporánea, Ed. Guadarrama, Madrid, 1968, p., 134). En parecidos términos se expresa J. Domingo, quien sostiene que «la gregueria se impuso de tal modo al escritor [...] que toda la novela de Ramón es una inmensa greguería, o un inmenso conjunto de greguerías». (J. Domingo, «Gómez de la Serna: la greguería en la novela", en La novela española del siglo $X X$, $\mathrm{t}$. I, Barcelona, Labor, 1973, p. 112.) De parecida opinión es Gaspar Gómez de la Serna, que afirma que «Lo que Ramón lleva a cabo con la novela está, naturalmente, condicionado a su modo de experiencia, a la estética general de la greguería". (Gaspar Gómez de la Serna, Ramón, Madrid, Taurus, 1963 , p. 128.) 
lo que, en definitiva, explicaría satisfactoriamente su frecuente interpenetración. Hemos de remitirnos, por tanto, a la estética general que preside la creación literaria de Ramón Gómez de la Serna para, posteriormente, redefinir la greguería y la novelística de nuestro autor con arreglo a este criterio, $y$, en último término, establecer la naturaleza de las relaciones que se observan entre ambas.

La impresión de heterogeneidad y dispersión que a simple vista produce la obra de Gómez de la Serna se disipa a poco que se profundice en ella. Se descubre entonces que esta obra, tan ingente en volumen como variada en géneros y formas, está alentada por un mismo espíritu creador y guiada por unas idénticas directrices artísticas, que enumeramos a continuación.

Uno de los fundamentos del sistema artístico de Gómez de la Serna es la visión plástica de la realidad, lo que implica que su discurso literario carezca de zona conceptual propiamente dicha. Todo en él se traduce a imágenes, a representaciones plásticas, como ha sido certeramente advertido ${ }^{2}$ y como puede constatarse en algunas de sus obras más representativas: Gollerias, Senos, El Rastro y tantas otras donde lo que importa es la traslación de la realidad a impresiones figurativas. Pero esta operación no sólo se produce en libros, como los citados, que tienen un referente concreto y material; también en obras cuyo tema sugiere un desarrollo conceptual o abstracto Ramón lo traslada a una dimensión plástica. Es el caso de Los muertos y las muertas, donde las ideas de "muerte», utiempo", "nada" se concretan en imágenes y representaciones figurativas.

Intimamente ligado a la visión plástica de la realidad debe situarse otro de los elementos constitutivos del arte ramoniano. Nos referimos a la presencia de las cosas, "nervio de la obra de Ramón», en palabras de Francisco Ynduráin ${ }^{3}$. Pero no es la mera presencia de las cosas lo que caracteriza la literatura de nuestro escritor, sino la actitud que manifiesta ante ellas, el relieve y protagonismo que les otorga, el particular enfoque con que las abor$\mathrm{da}$, las relaciones que establece entre ellas, las nuevas significaciones que descubre, los aspectos inéditos que destaca y, en último término, la profusión con que aparecen en su obra. Ramón se siente poderosamente atraído por el mundo de los objetos, que llegan a ejercer sobre él una profunda fascinación. Y esta atracción -no simple curiosidad-implica una indudable vinculación afectiva, como el propio escritor se ha encargado de destacar ${ }^{4}$.

2 Entre otros, por Umbral y Camón Aznar. Escribe Umbral a este propósito que «nadie menos dotado que él para el lenguaje conceptuoso o abstracto. Ramón no mueve ideas sino imágenes». (F. Umbral, Ramón y las vanguardias, Madrid, Espasa Calpe, 1978, p. 46.) Por su parte, Camón Aznar, al señalar la plasticidad de las creaciones ramonianas, cree que «Hay que buscar sus paralelos no en la literatura sino en el arte". (J. Camón Aznar, Ramón Gómez de la Serna en sus obras, Madrid, Espasa Calpe, 1972, p. 72.)

${ }^{3}$ F. Ynduráin, «Sobre el arte de Ramón», en Clásicos modernos, Madrid, Gredos, 1969, p. 200.

4 "Lo que me caracteriza es la ternura por las cosas que hay en lo más recóndito de mí. 
La actitud cordial hacia los objetos tiene como consecuencia inmediata su personificación, otra de las claves del mundo literario ramoniano, que ha llevado a algunos a hablar del peculiar animismo de Ramón ${ }^{5}$. No hay objeto, por insignificante que sea, que no aparezca revestido de algún indicio humanizador. A veces se trata de un simple detalle, pero en ocasiones se realiza una auténtica caracterización psicológica del objeto en cuestión, al que se dota de una personalidad propia e individual. Ramón ha descubierto, en efecto, la psicología de las cosas.

La personificación de las cosas tiene como necesario correlato en la estética ramoniana la cosificación $n^{6}$. Humanización y cosificación son, por tanto, las dos caras de un mismo fenómeno cuyo fundamento es la igualación prosopopéyica de personas y cosas, lo cual viene a representar una especie de uósmosis entre la conciencia y el mundo exterior que constituye el eje de su literaturas ${ }^{7}$.

Pero Ramón no nos ofrece sólo una visión humanizada de las cosas, sino que les añade una dimensión poética, consistente por lo general en mostrarlas mediante un variado registro de relaciones analógicas. Ramón somete a los objetos, en virtud de su poderosa intuición poética, a un dinamismo convergente o asociativo, no necesariamente de tipo metafórico, ya que, como apunta Camón Aznar, implica «analogías emotivas, contactos marginales en la forma y la función de las cosas relacionadas»" ${ }^{8}$.

Este singular mecanismo asociativo llevado a situaciones limite supone, en cierta medida, una tensión disgregadora, que viene a ser su complemento, y que podemos llamar imaginación divergente. La tendencia a adelgazar los vinculos de relación entre los objetos desemboca en la integración incidental de elementos heterogéneos, fórmula expresiva que se aproxima bastante a lo que Leo Spitzer denomina enumeración caótica' ${ }^{9}$, pero que también mantiene indudables concomitancias con la escritura surrealista, en cuanto trata de desvelar las insólitas afinidades que subyacen en el inconsciente, como el propio Ramón ha sugerido ${ }^{10}$.

Los dos tipos de relaciones descritos arriba poseen, no obstante su apa-

Asi como hay protector de animales, yo soy el protector de las cosas", en "Las cosas y ei ello", Madrid, Revista de Occidente, t. XLV, 1934, p. 191.

5 Tal es el caso de Umbral, que apunta que Ramón «funciona como los niños y los primitivos, mediante el pensamiento mágico y el animismo". (Op. cit., p. 255.)

6 Aparte de las múltiples cosificaciones ocasionales que podemos encontrar en todas las obras de Ramón, hay casos de cosificación sistemática, como en el libro Senos.

7 J. Camón Aznar, op. cit., p. 35.

8 Ibid., pp. 53-54.

9 Véase Leo Spitzer, "La enumeración caótica en la poesia moderna", en Lingüistica e historia literaria, Madrid, Gredos, 1968, pp. 247-291. tido. 
rente oposición, un factor común: el azar, lo imprevisible. Y ello se explica por la peculiar índole creativa del arte de nuestro autor, basado más en la intuición que en la premeditación o la reflexión, ya que, como apunta F. Ynduráin, Ramón «no fue hombre de ideación sistemática, pues procedia por un asociacionismo mental e imaginativo deliberadamente caprichoso" " $"$. Hasta tal punto, que puede afirmarse que ha abolido en sus creaciones las leyes de la causalidad para instaurar en su lugar el imperio de la casualidad, según indica, glosando al escritor, J. Camón Aznar:

«Su sistema literario consiste, como él mismo dice, en el choque de las cosas en el alma "al tropezar entre sí por pura casualidad" [... y esa casualidad $[$ [...] es la que le proporciona afinidades insospechadas"

Otro factor de singular importancia para comprender la estética de Gómez de la Serna es el acronismo, dato éste que, incomprensiblemente, no ha sido apenas advertido por la crítica $^{13}$. La raíz del acronismo esencial que preside la obra de Ramón hay que buscarla tanto en el azar como en la transfiguración imaginativa a que somete las cosas. El azar, que gobierna las intuiciones momentáneas con que Ramón sorprende la realidad y que es lo que proporciona a las imágenes resultantes su calidad inédita, implica, en efecto, la anulación de todo lo que suponga proceso o desarrollo. De igual manera que la proliferación de imágenes, en las que los objetos son extraídos de su devenir real para relacionarlos en un ámbito puramente mental, supone la ausencia de toda dimensión temporal.

También es característico del arte literario de nuestro autor el fragmentarismo. Ramón procede en sus creaciones mediante atisbos aislados, revelaciones súbitas y atomizadas, que lejos de integrarse en un discurso subordinante, se comportan como mónadas independientes, conservando una autonomía casi total. Los textos de Ramón son el resultado de una simple adición de elementos más que de una trabazón orgánica de los mismos, por lo que la discontinuidad constituye una de sus notas dominantes. El fragmentarismo, cuya expresión más genuina es la greguería, afecta a la escritura de Ramón en todos sus niveles, advirtiéndose incluso en la forma externa o diseño editorial de sus libros, integrados todos ellos por numerosas y breves unidades textuales.

Especial atención merece la forma en que Ramón transforma literariamente la realidad. Y en este sentido, uno de los postulados básicos de la esté-

11 F. Ynduráin, Prólogo a Museo de reproducciones, Barcelona, Destino, 1980, p. 16.

12 Op. cit., p. 69.

13 Excepción hecha de Camón Aznar, op. cit., pp. 62-64, y Jorge Urrutia, «Ramón Gómez de la Serna», en El Novecentismo y la renovación vanguardista, Madrid, Cincel, 1980, p. 53. 
tica ramoniana es la recusación del realismo -entendido en su acepción más usual-y la instauración de la invención de lo insólito como exigencia inabdicable del escritor. Ramón subvierte los términos de la mímesis aristotélica al afirmar la preeminencia de la imaginación sobre la realidad y sus representaciones más o menos fidelignas. Su obra pretende ser no una colección de hechos, situaciones, detalles extraídos de la gastada epidermis de la realidad, sino una aventura en lo recóndito e insospechado: una "antología de lo imposible» ${ }^{14}$. No debe inducir a engaño su actitud ante lo real, porque, en el fondo, Ramón es un convencido realista, ya que las cosas constituyen uno de los fundamentos de su arte. Lo que ocurre es que nos las ofrece en sus aspectos inéditos, contempladas desde ángulos imprevistos, convertidas en pura fantasmagoría por medio de la invención. Puede decirse, por tanto, que la literatura de Ramón es «tan inverosímil como veraz»" fantástica como arraigada en lo cotidiano.

Para cerrar esta síntesis de la estética ramoniana aludiremos a su presunto humorismo, aunque nosotros preferimos llamarlo actitud lúdica, que es algo sustancialmente diferente. Tal vez del sentido lúdico que subyace en toda la obra de Ramón deriven ocasionalmente ciertos rasgos de humor; pero no es éste lo que más propiamente le caracteriza. Como acertadamente apunta Umbral, "toda su obra tiene un planteamiento de juego", y su posible humorismo no es «sino la exteriorización más banal de su alma lúdica» ${ }^{16}$. Ramón en su obra juega con todo: con el lenguaje, con la imaginación, con las convenciones literarias, con las cosas. La literatura es para él un juego constante. Con la pasión lúdica de un niño descompone y recompone el universo, deshace y recrea los mecanismos de la literatura, desintegra y refunde, en delirante amalgama, la anatomía de la realidad, inventa sucesos y colecciona improbabilidades, mira las cosas con ojos adánicos, como si en cada momento se creara el mundo.

Todos los rasgos apuntados anteriormente como configuradores del arte literario de Ramón pueden descubrirse en la greguería, que es, en último término, una síntesis de todos ellos, la cristalización en una fórmula personalísima de una singular manera de concebir la literatura.

Los intentos de definir o caracterizar la greguería a partir de alguno de sus atributos más sobresalientes no han producido resultados fructíferos.

14 Ramón Gómez de la Serna, «Prólogo a las Novelas de la nebulosa», en El hombre perdido, Buenos Aires, Poseidón, 1947, p. 13.

15 Melchor Fernández Almagro, recogido en Automoribundia, t. II, Madrid, Guadarrama, 1974, p. 783.

16 Op. cit., p. 144. 
La razón estriba en que esta especie literaria, a pesar de su aparente simplicidad, integra en su estructura rasgos muy diversos, que son precisamente los que hemos apuntado como distintivos de la estética general de su creador. Por eso, ni la metáfora, ni el humor, aludidos en la conocida definición - "metáfora + humorismo $=$ gregueria»-, ni otras definiciones más o menos sugestivas o ingeniosas, ni, como pretende Senabre, el «juego de significantes ${ }^{17}$ pueden servir por sí solos para caracterizar adecuadamente esta especie literaria. Siempre queda algún cabo suelto que escapa a estas definiciones; siempre pueden encontrarse greguerías que no respondan a estas formulaciones ${ }^{18}$.

Respecto a la constitución básicamente metafórica de la greguería, cabe objetar que no todas siguen este procedimiento, aunque la proporción de las que lo observan es considerable. Pero una definición de esta indole resulta restrictiva, pues en muchas greguerías la analogía entre los términos relacionados es más sutil e imprecisa que la que la propia metáfora requiere, como podemos apreciar en estos ejemplos:

Hay árboles que dan gritos verdes. El miope huele todo con los ojos.

Hay que hablar, pues, de relaciones asociativas o analógicas, que pueden manifestarse de diferentes formas, no necesariamente mediante la metáfora.

La plasticidad como elemento configurador de la greguería es también evidente, y es extraño que el profesor Senabre afirme que «El carácter visual no es propio de todas las greguerías -más aún: ni siquiera de la mayor parte de ellas-y que, por consiguiente, tampoco este dato es un punto de apoyo firme en el que basar un estudio del género" ${ }^{19}$. Forzosamente tenemos que disentir de esta opinión, pues aparte de las numerosas greguerías cuya plasticidad es intrínseca, por tratarse de correspondencias entre objetos concretos y materiales, hay un número no desdeñable en que las ideas de amor, muerte, miedo, vida, tiempo, etc. se expresan mediante impresiones plásticas ${ }^{20}$ :

17 R. Senabre, «Sobre la técnica de la gregueria», en Papeles de Son Armadans, XLV, 134, 1967 , p. 136.

18 En el prólogo a Total de greguerías, Madrid, Aguilar, 1962, Ramón recoge un amplio repertorio de posibles definiciones de esta especie literaria y realiza una amplia exposición acerca de todos los parentescos que se le han señalado.

19 Art. cit., pp. 124-125.

20 Que Ramón tenia una noción esencialmente plástica y figurativa de las greguerías lo demuestra el hecho de que él mismo compusiera numerosas ilustraciones inspirándose en ellas, tal como puede comprobarse en la edición citada de Tocal de greguerias. 
El miedo es un ratón que se nos mete en el corazón.

Los recuerdos encogen como las camisetas.

El ensueño tiene los ojos sin agujerear de las estatuas.

No vamos a insistir en otros rasgos, como el protagonismo de las cosas, el azar, que preside sus insólitas relaciones, o el acronismo que se desprende de su captación intuitiva y momentánea, por tratarse de algo tan evidente que no necesita comentario.

Si queremos destacar, sin embargo, la personificación, pues es ésta una nota distintiva de un gran número de greguerías:

El huevo nos mira con su pupila interior.

Lloraba de frio la noche.

Las azucenas llevan los guantes a medio poner.

Soda: agua alegre.

El hormiguero es el calambre de la tierra.

Paralelo y complementario de la animación, se observa en buena parte de las greguerias el fenómeno de la cosificación, que suele implicar asimismo una humanización de los objetos que sirven de referencia cosificadora.

Las piernas de las mujeres son de piedra ablandada.

El cascarrabias tiene boca de cascanueces.

El sentido lúdico es también patente en todas las greguerías, aunque no debe confundirse, como hemos visto, con el humor. Tampoco debe restringirse a los juegos estrictamente lingüísticos, que son los que Senabre considera en su caracterización del género, pues éstos no son sino una de las realizaciones particulares de un principio más amplio que está en la base de todas las greguerías. Pero, además, no está en contradicción, como pretende el profesor citado, el sentido lúdico del lenguaje que informa una parte de las greguerías con la plasticidad y el resto de los rasgos que hemos considerado como configuradores de esta especie literaria.

Veamos a este respecto uno de los ejemplos que aporta el profesor Senabre para demostrar su tesis:

Los labios lividos del viento.

Nos hallamos en este caso ante un juego de significantes conseguido 
mediante una aliteración, que es lo que se percibe en primer término. Pero este mismo efecto está basado en una analogía fónica y posee, además, un evidente carácter plástico, por cuanto se dota de cualidades de forma y color a algo tan ajeno a ello como es el viento. Añadamos el carácter fortuito e insólito de las relaciones que implica, el acronismo propio de la intuición instantánea que sugiere, la personificación de lo inanimado y su condición fragmentaria, no discursiva, la presencia de las cosas o fenómenos como elemento referencial, aparte del manifiesto sentido lúdico, $y$ tendremos resumidos en una sola greguería todas las notas que hemos apuntado como caracterizadoras del género.

Ahora bien, aunque en la greguería se reproducen todos los rasgos que hemos apuntado como configuradores de la estética ramoniana, no en todas las greguerías aparecen en su totalidad. Pero todas ellas sí se conforman mediante la conjunción de varios de estos rasgos. Esta posibilidad combinatoria de unos elementos constantes es lo que proporciona a esta especie literaria la enorme variedad que posee, dentro de su unidad esencial.

También en la novela de Gómez de la Serna podemos encontrar todos los rasgos definidores de la estética general del escritor, adaptados ahora a la configuración particular del género novelesco.

Dato fundamental de muchos relatos ramonianos es la plasticidad, que afecta prácticamente a todos sus elementos integrantes: fábula, personajes, ambiente. La línea argumental se configura a menudo a partir de la representación plástica de la realidad. Novelas como El doctor inverosimil o La hiperestésica, basadas en conflictos anímicos, poseen un desarrollo netamente figurativo, pues sólo se pone de relieve aquello que puede percibirse visualmente: imágenes de una singular patología psíquica, forma y color de objetos que ejercen una influencia maléfica en los personajes, etc. No son éstos, sin embargo, casos aislados; en toda la producción novelística de Ramón la narración de acontecimientos se resuelve con frecuencia en un desfile de imágenes: centralizadas en un objeto ( $E l$ secreto del acueducto); en una serie de situaciones ( $E l$ incongruente); en un conjunto de reflexiones sobre la vida (El hombre perdido), o alrededor de una acuciante exigencia afectiva (iRebeca!). El sentido eminentemente plástico y figurativo de la narrativa ramoniana se acentúa por el protagonismo que adquiere el espacio, $e$, incluso, por la frecuente caracterización de los personajes a partir de una imagen o un detalle colorista o visual, como puede advertirse ya en el mismo título de algunas obras: La viuda blanca y negra, La virgen pintada de rojo, La mujer de ámbar, El caballero del hongo gris, La Roja, La Nardo y El pueblo de las morenas.

La presencia de las cosas es asimismo un factor de especial trascendencia en la configuración de la novelística de Gómez de la Serna. Las cosas in- 
vaden los relatos de Ramón hasta en sus más recónditos intersticios, y con frecuencia, la atención del escritor se distrae de la acción propiamente dicha para enredarse en una selva de objetos, lo que da lugar a abundantes digresiones marginales que obstaculizan la fluencia de argumento. Pero no siempre las cosas ocupan una posición secundaria, ya que son muchas las novelas en que es determinante su presencia en relación con el desarrollo de la fábula y el comportamiento de los personajes. Recordemos a este propósito La hiperestésica, cuya protagonista debe su desequilibrio al influjo nocivo de las cosas; o El doctor inverosimil, donde son precisamente las cosas los agentes de las enfermedades más extrañas; o El hombre perdido, cuyo anónimo protagonista se encuentra extraviado en una realidad laberíntica poblada de objetos perturbadores; o La abandonada en el Rastro, que acaba desintegrándose en un caótico montón de objetos.

La presencia de las cosas en la narrativa de Ramón nada tiene que ver con cualquier neutro descriptivismo. En todas se subraya algún detalle humanizador, de tal manera que vienen a constituir un retablo animado de la realidad sobre el que superpone la acción de los personajes humanos. $\mathrm{He}$ aquí un ejemplo suficientemente ilustrativo sobre el alcance de la técnica humanizadora en la novela ramoniana:

«Frente a sus balcones habia caído en un árbol una camisa azul, en la que el viento se ensañaba todos los días, desgarrándola un poco más. Vivía hacia dias el conflicto pasional de aquella camisa.

Estaba tomando más agua que nunca porque se le había ocurrido pensar que los vasos de agua matan la sed de los difuntos y de los dioses.

Se le interponía más que nunca el tigre domado del cepillo [...]

No metía casi nunca los zapatos en la ratonera de los cajones sino que les dejaba ser ratones, ilustrar su vida necesitaba de cosas para vivir, para contemplar la verdad de vivir.

Los zapatos debajo de la cama celebraban consejo de caminos y le ayudaban a saber que vivía” ${ }^{21}$.

La sistemática humanización de las cosas puede dar lugar a que éstas se conviertan en ocasiones en los auténticos protagonistas del relato, como ocurre en El farol 185 o El biombo (ambas incluidas en El novelista), o lleguen a adquirir la función de coprotagonistas (tal es el caso de $E l$ secreto del acueducto, La casa triangular, La capa de don Dámaso o Se presentó el hígado). En este sentido, Ramón no hizo sino realizar en la práctica lo que constituía uno de sus postulados teóricos acerca de la función de los personajes en la novela moderna:

«¿Pero es el momento de la novela de personajes? ¿No será mejor la novela de las cosas?" 2 .

21 iRebeca!, Madrid, Espasa Calpe, 1974, p. 204.

22 Prólogo cit., p. 15. 
En el polo opuesto a la animación de las cosas -aunque ambos fenómenos son convergentes-, puede hablarse de cosificación de las personas en la narrativa de Gómez de la Serna, precisamente por la influencia que sobre ellas ejercen los objetos. Es frecuente la presentación de los personajes mediante una reducción cosificadora, como en este ejemplo, perteneciente a El hombre perdido:

[...] Yo soy una radiografía que salió mal [...]

- Mas le voy a decir... soy el sillón que ya no sirve para el imposibilitado y la peluca del cómico viejo ${ }^{23}$.

O en este otro, extraído de La abandonada en el Rastro, en el que el personaje acaba disolviéndose en un monton de objetos:

"se disolvia en sombrero, dentadura postiza, sillón ortopédico, corsé papiro, cabeza de peinadora fracasada, ojos de cristal, cuerpo de prueba modistil, piernas de muestra de sedería y sombrilla colgada de los alambres tendidos como paraguas inocentes" ${ }^{24}$.

Respecto a las relaciones analógicas, es frecuente encontrarlas en la prosa novelesca ramoniana. No se limita nuestro autor a un descriptivismo funcional, sino que objetos y situaciones son transfigurados continuamente en virtud de relaciones asociativas, como puede apreciarse en este fragmento de La mujer de ámbar:

«La segunda enlutada fue un adefesio que parecía prendido con telarañas negras. Su disfraz de enlutada había estado fraguado con retales de lutos distintos y completado con piezas de remiendo.

No estaba desgarrado su manto y, sin embargo, daba una sensación de desgarramiento como llevando dos alas desgarradas y caídas.

El movimiento de sus caderas era lo único que ponía campanadas alegres a aquel luto triste» 25

Pero junto a este tipo de relaciones analógicas basadas en una evidente semejanza, más o menos remota, entre los términos relacionados, hallamos un conjunto de novelas -sobre todo las denominadas «de la nebulosa", aunque no son las únicas-donde la realidad se somete a un efecto desinte-

\footnotetext{
23 El hombre perdido, p. 35.

24 La abandonada en el Rastro, en Revista de Occidente, t. XXIII, Madrid, 1929, p. 283.

25 La mujer de ámbar, Madrid, Biblioteca Nueva, 1927, p. 46.
} 
grador o disociador, dando lugar a lo que hemos llamado imaginación divergente, mediante la cual se intenta dar cuenta de las misteriosas correspondencias que laten en el fondo de la realidad, tan auténticas y sugestivas como las que aparecen en su corteza:

«El secreto que buscaba era una mezcla de cosas al correr de su pensamiento, era el pitido del primer tren, mezclado a un ruido de agua, a la campanada de un reloj, al resplandor de una anchoa enrollada como un caracol en un frasco de variantes, al pulso en la muñeca de la mujer dormida, al brillo agonizante de un azulejo... ${ }^{26}$.

Este tipo de relaciones entre las cosas sólo es posible merced a su inesperada colisión en la conciencia, gracias, en definitiva, al azar. Pero el azar afecta también a los restantes elementos de la narrativa ramoniana: la acción obedece casi siempre a la impremeditación; no hay una necesaria relación casual entre los acontecimientos, como puede apreciarse en novelas como El incongruente o El hombre perdido; tampoco los personajes suelen tener un plan vital definido, $y$ es el azar el que determina sus vinculaciones.

Con estos presupuestos creadores, los relatos de Ramón tienden siempre a lo sorprendente y lo insólito, como si fuesen conducidos por una suprema libertad imaginativa. Nada es previsible en ellos; siempre salta la imagen sorprendente, el acontecimiento imprevisto. Hay que tener en cuenta, además, el propio carácter de los temas novelescos de Ramón, orientados hacia lo inédito y extraordinario, de lo cual nos pueden ilustrar algunos de sus títulos: El doctor inverosimil, El incongruente, El hijo superrealista, Palacio del psicoanálisis, Las siamesas, El dueño del átomo, Cinelandia, La hiperestética, o las series de "falsas" y "superhistóricas».

La novela de Ramón tiende asimismo hacia la fragmentación y el atomismo. Más que basados en la linealidad discursiva, los relatos ramonianos se construyen mediante la adición de secuencias fragmentarias y un tanto inconexas que obstaculizan el desarrollo progresivo de la acción. La discontinuidad afecta tanto al conjunto de la obra, cuya acción se fragmenta en múltiples incidencias anecdóticas, como a cada una de sus partes, atomizadas a su vez en multitud de impresiones, curiosidades e imágenes soldadas arbitrariamente, sin una fuerte cohesión interna. Novelas como El incongruente, El doctor inverosimil, iRebeca!, Cinelandia, El hombre perdido, y tantas otras, muestran claramente el carácter fragmentario de las creaciones novelescas de Ramón.

Consecuencia lógica del fragmentarismo y el azar es la dimensión acrónica de la narrativa ramoniana. Pero la ausencia de significación temporal obedece además a otras causas: percepción de la realidad en cada una de sus

26 iRebeca!, p. 179. 
innumerables partículas - las cosas-captadas instantánea e independientemente, que, convertidas en imágenes, son extraídas de su contexto, de su referencia espacial o temporal; abolición de las leyes de la causalidad; autonomía relativa de cada episodio, que no depende del anterior ni genera elsiguiente, con lo que se suprime todo sentido progresivo consustancial al tiempo; rígido trazado de los personajes, que no experimentan variación o transformación, como si vivieran al margen del tiempo. Cualquier relato de Gómez de la Serna de los aludidos anteriormente puede servir de ejemplo de la ausencia de dimensión temporal, pero podemos fijarnos en uno de ellos: El doctor inverosimil. No hay en esta novela desarrollo temporal, pues los múltiples episodios que la componen son independientes; sólo el tema común, la enfermedad, y la presencia del protagonista sirven de vínculo entre ellos. No se perciben, por tanto, relaciones de causalidad; cada uno de los capítulos es una mónada narrativa encerrada en si misma. El protagonista tampoco experimenta variación alguna en su carácter o comportamiento. La atención a lo concreto, a las cosas inmediatas, impide asimismo descubir cualquier atisbo de temporalidad.

En último término, cabe señalar el sentido lúdico de buena parte de las novelas de Ramón. Sentido lúdico que afecta tanto al lenguaje como a los temas y su desarrollo y a la actitud del autor hacia su mundo novelesco. Ramón juega con los géneros novelescos, como lo atestiguan las nuevas especies narrativas creadas por él: «novelas de la nebulosa», "falsas" y "superhistóricas». Juega con los temas, según se desprende del tratamiento festivo que imprime a algunos - como la enfermedad, en El doctor inverosimil-que sugieren otro enfoque. Juega con los personajes, a costa de su consistencia humana, tal como puede apreciarse en muchos de los protagonistas de sus relatos: El incongruente, El hombre de los pies grandes, La hiperestésica, Las siamesas, Cesárea (estas dos incluidas en El novelista), La casa triangular, El hijo superrealista, El vegetariano, etc. Juega con las ideas, los sentimientos, el lenguje. Toda su obra narrativa es, en definitiva, el resultado de una imaginación libre y lúdica.

Hemos podido constatar en las páginas que anteceden que tanto la greguería como la novela se ajustan en Gómez de la Serna a unos mismos presupuestos creadores: los que configuran la estética general del escritor. Si ambas especies literarias se asemejan en lo que podríamos denominar su estructura profunda, ello es debido, por tanto, a que responden, salvando sus diferencias genéricas, a un idéntico código literario. Y esta analogía contribuye a la ósmosis que entre ellas se produce a todo lo largo de la obra del autor. Pero de la notoria presencia -muy abundante en algunos casosde greguerías en las novelas de Ramón no puede inferirse en modo alguno - como ha venido haciéndose a partir de un superficial examen de asunto- 
que las claves de su sistema narrativo sólo puedan dilucidarse con la greguería como único punto de referencia. Los relatos ramonianos -ocioso es aclararlo- poseen por sí mismos todos los atributos propios del género novelesco y sus indudables conexiones con la especie literaria aludida no interfieren en su consistencia específicamente narrativa. Ahora bien, como tampoco puede pasarse por alto que la greguería desempeña un papel de cierto relieve en la configuración de la novelística ramoniana, es preciso, para evitar equívocos sobre su alcance y significado, determinar en qué medida y de qué manera contribuye a perfilar la prosa novelesca del escritor.

De su somero repaso de las narraciones de Gómez de la Serna se desprende la impresión - que una lectura más atenta corrobora-de que la greguería se distribuye en ellas con bastante irregularidad, por lo que es dificil establecer unas pautas fijas acerca de su incidencia. En cuanto a la frecuencia con que aparece, se observan notables oscilaciones de una obra a otra. Lo relatos de ambiente realista y corte más tradicional, sobre todo lo que por sus dimensiones pueden calificarse de «narrativa menor», son los que incluyen una proporción más reducida de greguerías. En el polo opuesto, las denominadas por su creador novelas de la nebulosa (grupo en el que cabe incluir El incongruente (1922), El novelista (1923), iRebeca! (1936) y El hombre perdido (1947), y al que podrian sumarse acaso El secreto del acueducto (1922) y Cinelandia (1923) las incorporan con gran profusión, hasta el extremo de que no es infrecuente que, con cualquier pretexto, se dispongan en serie, como en este ejemplo extraído de Cinelandia:

"Tomy tenía las frases de niño prodigio, que en vez de vivir entre las faldas complacientes de su primer doncella perfumada y bayadérica, vivía sobre sus senos.

Algunas de sus frases recorrían Cinelandia:

- Hoy ha dicho Tomy que el elefante es un animal de procesión [...]

-Hoy ha dicho Tomy que todos los personajes del cine son mineros enriquecidos.

- Hoy ha dicho Tomy que la piña es un adorno arquitectónico que se come.

- Hoy ha dicho Tomy que el acordeón suena a sótano triste [...]

- Hoy ha dicho Tomy que la enorme boca del hipopótamo es el buzón para las cartas dirigidas a Mesopotamia»" ${ }^{27}$.

Las greguerias insertadas de esta manera en el texto narrativo parecen a simple vista un elemento postizo dificil de armonizar con el resto de los componentes del relato. Para atenuar un tanto este efecto, suelen figurar como parte del sistema expresivo de un personaje excéntrico, que, además,

27 Cinelandia, Valencia, Ed. Sempere, 1923, pp. 94-95. 
tiene por lo general un carácter autobiográfico, como ocurre, por ejemplo, en $E l$ secreto del acueducto, El incongruente y iRebeca? ${ }^{28}$.

Son más frecuentes las ocasiones en que la greguería se halla plenamente integrada en el tejido narrativo, imprimiendo a las diferentes situaciones una singular potencia sugestiva, tal como se puede apreciar en este fragmento de El torero Caracho:

«Los picadores, ya con más disciplina, parecían ir a saltar a la garrocha sobre el toro; pero se contenian y esperaban muy marrajamente a que el toro acabase de poner su inyección de cuerno a los caballos [...]

Cairel, después, con su arte solemne, trazó con la muleta unos signos de última bendición, $y$ después de atizarle media en las agujas pinchó un descabello a pulso como si hubiera sido un delineante y hubiera clavado el compás a la perfección.

La ovación fue empedernida, porque muchas palmas eran como pedernales de que salían chispas, palmas de piedra en que parece que aplauden los si$\operatorname{glos}^{29}$.

En determinadas circunstancias la greguería asume un protagonismo casi exclusivo; por ejemplo, en la presentación de ambientes y cosas, sobre todo si en el relato desempeñan un papel relevante. El procedimiento, similar al empleado en libros tan genuinamente ramonianos como El alba, Los muertos y las muertas, Senos, etc., se basa en la acumulación de variaciones sobre un tema, sin que aparentemente se perciba un designio organizativo:

(Toda la acacia es graciosa. No es el árbol de hojarasca estúpida y revuelta. La acacia es japonesa. Esa sutileza de color y de forma que la distinguen son japonesas. Es el árbol trabajado como por un orfebre, trabajado en concha, y resultando por eso de algún modo las peinetas de Madrid, las peinetas de la multitud de mujeres del pueblo, las peinetas de los paseos.

La acacia es consolatriz en las horas de sol fuerte, porque salpica como una regadera. iFina regadera!

Bajo la canícula hay alrededor de ellas un resplandor rubio, como si revolotease el verde sobre el verde. Tanto toman el sol y lo esponjan, que al atardecer queda en su copa cierta incandescencia, cierto tono de grandes escarabajos de oro.

En las rondas y en las grandes avenidas de Madrid son las acacias nuestras grandes sombrillas, sombrillas de seda que no apagan ni la luz ni el calor, como debe suceder. iDucha fina y sutil! ${ }^{30}$.

28 Cfr. El secreto del acueducto, Madrid, Biblioteca Nueva, 1922, pp. 61-66; El incongruente, Madrid, Espasa Calpe, 1922, pp. 116-117 y iRebeca!, ed. cit., p. 54.

29 El torero Caracho, Madrid, Agencia Mundial de Librería, 1926, pp. 197-198.

30 La malicia de las acacias, Valencia, Ed. Sempere, 1927, pp. 8-9 (incluida en el libro de relatos que se abre con esta obra, que da título al volumen; la primera edición de esta novela, de 1923, no incluye este pasaje). 
La greguería, como vemos, es un recurso que por su gran versatilidad puede adaptarse a cualquier situación narrativa: creación de ambientes, relación de sucesos, diálogos, caracterización de personajes, reflexiones, digresiones, etc., por lo que resultaría ímprobo inventariar, siquiera de forma aproximada, sus realizaciones posibles. La razón principal de su ubicuidad y fácil aclimatación a cualquier coyuntura de la novela estriba -aparte su íntimo parentesco- en que Ramón sacrifica el decoro y la verosimilitud postulados básicos del realismo, tan denostado por él-en beneficio de la invención estilística, cuyo eje medular es la greguería. Contribuye a ello el hecho de que la voz de los personajes y del narrador sea asumida por el propio autor, en detrimento de su autonomía y consistencia. De ahí la indiferenciación de voces que se observa en los relatos ramonianos; porque en realidad sólo hay una voz que se deja oír en todo el ámbito novelesco: la del autor. Una voz que posee, digámoslo así, un matiz dominante, la greguería, que la hace fácilmente identificable y que delata de manera inequivoca a su propietario $^{31}$. Así pues, la presencia de la greguería en la novela ramoniana actúa como elemento unificador e indiferenciador en el plano estilístico, aunque, como veremos, su repercusión en otros aspectos es de signo muy distinto.

En efecto, en lo que se refiere al desarrollo narrativo, la greguería es siempre un factor de desintegración. Qué duda cabe de que en todos lo relatos de Gómez de la Serna puede hallarse una línea argumental netamente perfilada; pero también es cierto que ese decurso de acontecimientos se quiebra a cada paso como consecuencia de esos momentáneos -o sostenidos, según los casos- excursos que constituyen las greguerías. De tal suerte que la narración se va configurando mediante la interacción de dos fuerzas antagónicas: una cohesiva, centrípeta, representada por la fábula propiamente dicha, y otra disgregadora, centrifuga, cuyo núcleo es la greguería. $Y$ esta tensión, con sus diferentes alternativas, en función de la fuerza dominante, es uno de los rasgos que mejor definen la novelística de nuestro autor.

El análisis efectuado nos ha permitido desarrollar una -así lo estimamos- razonable interpretación sobre la naturaleza de las relaciones entre la greguería y la novela; pero no queremos concluir esta breve aproxima-

31 Empleamos el término en un sentido diferente al que le otorgan W. Booth, en The rhetoric offiction (trad. española: La retórica de la ficción, Barcelona, Bosch, 1974) y Oscar Tacca, Las voces de la novela, Madrid, Gredos, 1978. La acepción que aquil le damos coincide básicamente con lo que U. Eco denomina presencia textual del autor como un estilo reconocible. Las otras modalidades en que el autor puede manifestarse textualmente (puro papel actancial y aparición inlocutoria) no nos interesan en este caso. (Véase Umberto Eco, Lector in fabula, Barcelona, Ed. Lumen, 1981, p. 88). 
ción al asunto sin referirnos a un aspecto que precisamente es el que ha suscitado mayor controversia: su evaluación crítica.

Las apreciaciones negativas coinciden en que la greguería es un elemento perturbador que no sólo no aporta nada sustantivo a la novela, sino que «constituye más bien una rémora, porque paraliza la marcha normal de la acción $"{ }^{32}$. Todas las descalificaciones de esta índole parten del supuesto de que la acción constituye el ingrediente verdaderamente caracterizador del género, y desde esta perspectiva, claro está, la greguería no puede justificarse. No obstante, hay quien, sin llegar a desprenderse de este prejuicio, estima que la greguería también ejerce en la narrativa de Gómez de la Serna un efecto beneficioso, ya que

«enriquece y adorna sus novelas, hace su prosa apta para captar detalles y momentos de sutileza y vivacidad excepcionales; es, en general, un instrumento expresivo maravillosamente idóneo en la creación o sugestión de un determinado ambiente novelesco. Pero -según observa J. Marías-, al detener y fijar las cosas en esa especie de fogonazo instantáneo que es siempre la gregueria, lo propiamente novelesco se estanca, la acción no fluye.... ${ }^{33}$.

Una conclusión sustancialmente idéntica arroja el balance que sobre la cuestión realiza Gaspar Gómez de la Serna:

«El déficit producido por la estética de la gregueria en el género novela puede referirse principalmente al método, a la vez espontáneo y discontinuo de construcción, el cual entrecorta la acción, yuxtaponiendo escenas, planos y episodios, aglomera los elementos sin seleccionarios de acuerdo con exigencias puramente novelescas [...] empobreciendo la fábula o asunto propio y también el alma de los personajes [...]

Si ahora queremos aludir a lo que el ramonismo añade a la novela, veremos que no es menos que precisamente esto: literatura [...]

La invasión multiplicada de la propia realidad que se interfiere en el proceso novelador, entrecortándolo, aumenta enormemente la capacidad expresiva de la propia realidad, sea ésta ambiental o humana.... ${ }^{34}$

Eficacia estilistica, pero torpeza narrativa: éste parece ser el dictamen que ha prevalecido a la hora de enjuiciar la función de la greguería en las novelas de Ramón, dictamen que, en nuestra opinión, no se basa en un planteamiento crítico adecuado. Para una valoración más rigurosa del fenó-

32 J. M." Martinez Cachero, «Poetas y prosistas del novecientos», en Historia General de las Literaturas Hispánicas, t. VI, Barcelona, 1973, p. 415.

33 Eugenio G. de Nora, La novela española contemporánea, t. II, Madrid, Gredos, 2." ed., 1968, p. 104.

34 Op. cit., p. 131. 
meno es preciso examinarlo, como ya advertimos al comienzo, desde sus coordenadas literarias específicas y no mediante la aplicación indiscriminada de esquemáticos principios doctrinales -como lamentablemente ha venido haciéndose en este caso, con los resultados ya conocidos-, pues si hay algún género e que el enfoque normativo resulte particularmente inadecuado éste es la novela, forma -resulta enojoso aclararlo-flexible y proteica por naturaleza, como su historia, y sobre todo la más reciente, se ha encargado de demostrar.

Situados en una perspectiva inmanente, el panorama experimenta una sensible transformación, y lo que con otros criterios resultaba recusable, ahora presenta matices más positivos. Pero no vamos a insistir en la razón fundamental -ya expuesta en todos sus pormenores- en que se apoya la convivencia entre greguería y novela; ahora vamos a limitarnos a evaluar algunos de sus efectos.

En contra de lo que se ha afirmado, la greguería no atenta en ningún caso contra el desarrollo de la acción novelesca, sino que, en todo caso, contribuye a atemperar su ritmo, ya que el soporte anecdótico de la narracción ramoniana se suele configurar mediante la acumulación, a veces desbordante, de episodios fugaces. Con todo, los relatos de Ramón no son menos fluidos, a causa de la greguería, que otros tipos de novela de nuestro tiempo (psicológicas, descriptivistas, etc.) que han sido reputadas como grandes creaciones dentro del género; $y$ en cambio, gracias a ella, cobran una inusitada vivacidad imaginativa.

Por otro lado, la singularidad expresiva de la greguería es solidaria de los demás elementos de la narración, orientados siempre en Ramón hacia lo sorpresivo y lo insólito, tanto en lo que se refiere a los personajes, como a los temas y a la invención anecdótica. La integración de la gregueria en la novela ramoniana es, como podemos apreciar, plenamente simbiótica, en contra de los que opinan que es un aditamento suplerfluo.

Por último, queremos llamar la atención sobre el papel ejercido por la greguería en la renovación de la prosa novelesca. Ramón ha conseguido, en efecto, gracias en no escasa medida a este instrumento expresivo, dotar al lenguaje de la novela de una dimensión sugestiva, casi taumatúrgica, sin precedentes en nuestra historia literaria; lo ha liberado de la opacidad y la servidumbre utilitarista para hacerlo brillar con luz propia. Ha logrado hacer de él un protagonista más (algo que muchos han intentado después no con tanta fortuna), de tal manera que en sus relatos, paralela a la peripecia de los personajes, discurre la prodigiosa aventura de su lenguaje; y, lo que es más admirable, sin que ambos se estorben, porque el interés estilístico nunca va en detrimento de los valores propiamente «novelescos». Este es uno de los logros indiscutibles de Gómez de la Serna como novelista; logro al que la gregueria contribuyó de forma significativa en virtud de la idéntica configuración esencial de ambas especies literarias. 